\title{
The Contemporary Stereotype of the Polish Gentry and its Historical Conditions
}

\author{
U.Świderska-Włodarczyk
}

For citation: Świderska-Włodarczyk U. The Contemporary Stereotype of the Polish Gentry and its Historical Conditions. Vestnik of Saint Petersburg University. History, 2020, vol. 65, iss. 2, pp. 491-501. https://doi.org/10.21638/11701/spbu02.2020.209

Stereotypes constitute an important means of explaining past and present reality. Therefore, they are a significant component of consciousness of all times and places. In this context, stereotypes have always been associated with the conscious propaganda of contemporary power centers. In practice, they enable not only to degrade competitors, but above all they occupy a permanent place in the mass consciousness. In the end, these efforts aim at embedding stereotypical beliefs about the value or anti-value of certain individuals, social groups and entire nations. Moreover, even when the validity of a given propaganda wanes, the once-established stereotype remains alive. The contemporary stereotype of Polish nobility is not only a product of our time. Old Polish preachers, intellectuals of bourgeois and peasant origin, anti-Polish spokesmen and antinobility propaganda promoted during the partitions, as well as architects of the post-war political system who made the nobility the number one enemy worked within this frame of mind. The final effect is a clearly negative image of a modern nobleman. To a large extent, it has been based on an equally negative stereotype. It is confirmed by a survey conducted in the selected groups of high school students, university students and $\mathrm{PhD}$ students. The same conclusions can be made on the analysis of school textbooks and direct observation of media communication on educational portals. They all comprise a collective portrait of native nobility, in which flaws take precedence over merits, while the slogan that has been popular nowadays - "the nobility does not work" - should be considered the essence of antinobility myth.

Keywords: Polish gentry, stereotype, myth, image, personal model, antimodel, noble values, moral standards, propaganda, Sarmatism, tradition, culture.

\section{Современный стереотип представлений о древнепольском дворянстве и его исторические обусловленности}

\section{У. Щвидерска-Влодарчик}

Для цитирования: Świderska-Włodarczyk U. The Contemporary Stereotype of the Polish Gentry and its Historical Conditions // Вестник Санкт-Петербургского университета. История. 2020. T.65. Вып. 2. С. 491-501. https://doi.org/10.21638/11701/spbu02.2020.209

Стереотипы, являясь средством объяснения прошлой и настоящей реальности, являются важным элементом осознания времени и пространства. Они позволяют простым

Urszula Świderska-Włodarczyk - Dr. hab., Professor, University of Zielona Góra, 69, ul. Wojska Polskiego, Zielona Góra, 65-625, Poland; uswid@wp.pl

уршула Щвидерска-Влодарчик - Dr. hab., проф., Зеленогурский университет, Польша, 65-625, Зелёна-Гура, аллея Войска Полского, 69; uswid@wp.pl

(c) Санкт-Петербургский государственный университет, 2020 
и однозначным способом определить и обосновать прошлое и следующее из него настоящее, отмеченное типичной системой общественного порядка, а также доминирующими политическими силами и действующей иерархией ценностей. В этом контексте стереотипы всегда связаны с пропагандой актуальных центров власти. На практике они позволяют не только дезавуировать конкурентов, но прежде всего занимают постоянное место в общественном сознании. Конечным результатом является включение в это сознание стереотипных представлений о ценности или антиценности отдельных людей, социальных групп и целых наций. Более того, даже когда подобная пропаганда перестает быть актуальной, некогда сложившийся стереотип продолжает жить в сознании. Следовательно, современное стереотипное представление о польском дворянстве - не только продукт нашего времени. Его носителями выступали древнепольские проповедники, интеллигенция мещанского и крестьянского происхождения, выразители антипольской, а значит, и антидворянской пропаганды, популяризируемой в период разделов Польши, а также архитекторы послевоенной политической системы, которые сделали из дворян классового врага номер один. В итоге появился однозначно негативный образ современного дворянина. В значительной степени он основан на столь же негативном стереотипе. Этот тезис подтверждается анкетированием, которое проводилось в выбранных группах старшеклассников, студентов и докторантов. Такие же выводы дал анализ школьных учебников и непосредственное наблюдение информационных сообщений на образовательных порталах. Все они составляют коллективный портрет местного дворянства, недостатки которого преобладают над положительными качествами, при этом квинтэссенцией антидворянского мифа следует считать популярный сегодня девиз: «Шляхта не работает».

Ключевые слова: польское дворянство, шляхта, стереотип, миф, образец, личный идеал, антиобразец, дворянские ценности, нравственные ориентиры, пропаганда, сарматизм, традиция, культура.

Both stereotypes and the myths related to them have survived to see many definitions written from the perspective of sociology, pedagogy, literary studies, cultural studies, psychology, philosophy or history. In the context of this issue, it is not necessary to make a detailed analysis of the existing arrangements. It is enough to refer to the common understanding of these terms. Therefore, by stereotype, I shall understand a generalised mental structure formed as a result of multiple repeated associations, usually negative in nature, translating into a collective prejudice against unacceptable individuals and social groups. A myth, on the other hand, is a kind of superstition rooted in common consciousness, fabrication $^{1}$ and historical fallacy, distributed - just as the stereotype - more or less consciously.

Stereotypes and myths belong to the canon of means that explain the past and present reality. Hence, they form an important component of awareness in all times and in all places. They enable to simply and unambiguously determine and justify the past and the resulting present, labelled with a typical system of social order, as well as the dominant political forces and the existing hierarchy of values. In each of these variants, the most privileged positions are reserved for supporters of the current centre of power. However, in order to confirm their position and views, the latter must find a historical or contemporary argumentation which will consequently become a collective and individual trademark of the ruling circles. The same regularity applies to the groups aspiring to the role of a hegemon. In order to assume physical and spiritual power, one must refer to the S. 13.

${ }^{1}$ Klik M. Teorie mitu. Współczesne literaturoznawstwo francuskie (1969-2010). Warszawa, 2016. 
founding myth and outer symbols; to give new meanings to reality; to impose own moral paradigm.

History and propaganda are among particularly effective measures leading to the implementation of such objectives. One simple truism at this point is to state that each generation redefines the knowledge about the past. However, in the case of the undertaken issue, it is fully justified as it clearly indicates that history is not entirely objective as a science. It very often serves the current ideology. It becomes, as noted by Henryk Samsonowicz, a collection of myths, written for the present needs, which make it difficult to introduce new theses ${ }^{2}$. Hence, history is always threatened by propaganda, although compared to propaganda in the strict sense, it seems to be less categorical, while retaining some semblance of objectivity ennobled with the patina of time. Moreover, there is a feedback loop between history and propaganda. The stereotype used as a weapon against the enemies (political or economic), and so clearly false and unjust, very often becomes half-truth or reversed historical truth, presented as an obvious and indisputable fact. On the basis of a simplified template or an intellectual illusion, it assumes a permanent place in the consciousness of the general public. The final result of this is that awareness is enriched with stereotypical myths and mythologised stereotypes. In this context, the boundary between a myth and a stereotype becomes flexible. The effect follows the cause, but the same effect becomes a condition for the next metamorphosis of the original cause, which turns into a new quality compliant with the current propaganda. Moreover, even if that propaganda wanes, the stereotype remains alive. It loses its justification but does not die with it. Due to the long duration, it takes on the nature of cardinal truth, indifferent to arguments, eternal and unconditional, embedded in the collective consciousness and a sense of identity.

So understood, the stereotype is intertwined with the old and the contemporary image of a gentry man. It is hard to resist the impression that, in common perception, gentry is more associated with an anti-model, which suffered from a number of defects, destructive for the fate of Poland. In order to verify this opinion, I have analysed old and modern sources communications and currently applicable history schoolbooks. I have also considered reasonable to carry out surveys on selected groups of secondary school students, university students and doctoral candidates supplemented by a direct observation of media communications and social networks. They all contribute to the final collective portrait of Polish gentry.

The negative stereotype of gentry is not only a product of our times as it never had a good press. This is confirmed by numerous allegations formulated by the Polish clergy. Even Jan Długosz complained about effeminacy of the gentry and abandonment of the ideals of ancestors. The intensity of the criticism seems to grow in direct proportion to the elapsed time. In the $16^{\text {th }}$ and the $17^{\text {th }}$ century, a wider range of comments came from the church articulated by authority figures such as Andrzej Frycz Modrzewski, Piotr Skarga, Szymon Starowolski and others. They all unanimously accused contemporary gentry of many flaws. However, the most serious accusations concerned abandoning chivalric obligations for the sake of the convenience of noble life, giving up concerns about Poland to replace them with private interest, self-interest and anti-civic attitude. Plebeian communities were also eager to criticise. It is especially evident in the so-called picaresque literature showing the distorted customs and morals of gentry.

${ }^{2}$ Samsonowicz H. O “historii prawdziwej”. Mity, legendy i podania jako źródło historyczne. Gdańsk, 1997. S. 72. 
In no case, however, can the above constitute credible evidence of the actual corruption and fall of the representatives of a privileged status. We should rather see it as symptoms of class conflicts having competitive, ideological and economic origins. The underlying reasons include disputes between the clergy and gentry about the tithe, prenuptial announcements, tax burden and the jurisdiction, as well as the importance of the promoted priorities which comprise civic duties. Reading the reviews on this written by modern preachers, it is hard to resist the impression that, mentally, they remained in the medieval reality, when war constituted the economic basis of income. It is known, however, that the decline of this era was marked by the economic re-evaluation resulting in a shift of income sources onto agricultural production, implemented within the framework of gentry's farms. In the new situation, the owners had to reorient their skills and become competent managers of agricultural enterprises, which not only guaranteed money for them, but also for Poland, which functioned thanks to taxes paid by these farms. The clergy did not seem to notice this dependence. They preferred to dramatically call on the farms' owners to abandon their homes, just like medieval knights did, and to keep watch at the borders and face invaders - which would definitely undermine the economic basis, not only for gentry, but for the entire state. It is worth noting that calling to arms was not justified in the relatively peaceful $16^{\text {th }}$ century and in the subsequent one filled with endless war, when the representatives of the Polish gentry actively participated in the struggle against foreign invaders. Still, those dramatic calls were a great tool for the clergy's propaganda aimed at political competition. Additionally, the amount of this propaganda grew along with the emancipation of gentry, the members of which became decision-makers in politics and were critical of the Polish clergy. Allegations from the middle class have a slightly different basis. Although to some extent, they warn about the political competence, they primarily focus on the economic promotion. Besides, gentry itself was not a monolith. We know about the conflicts between less influential noblemen and magnates, or between orthodox Catholics and religious dissenters. In any case, this fight used a tool of propaganda against gentry, but also by gentry against their adversaries. Old Polish literature is full of derogatory opinions on the clergy, middle class and peasants. However, it is hard not to notice a specific trend, present in the Polish historiography, which treats accusations against gentry as factually correct, while allegations formulated by gentry are considered to be evidence of its megalomania, ethical shortcomings and ruthless attacks on opponents.

Another phase of anti-gentry propaganda are the times of the Polish Enlightenment. It was primarily led by Stanisław August Poniatowski, a ruler who was unreliable in the eyes of the gentry because of his Russian connections, and additionally an author and initiator of numerous reforms, valuable but controversial, upsetting the existing order. This alone is a good reason for the emergence of fractions: royal supporters and the opposition from gentry. In order to disavow this opposition, royalists used a rich arsenal of propaganda measures on an unprecedented scale. The magazine Monitor, published by supporters of the ruling camp, was designated for the purpose. On its pages, in addition to promoting the objectives of education and tolerance - values by all means worthy of approval - authors consistently condemned vices allegedly typical of gentry: backwardness, conservatism, laziness, idleness, fanaticism, proneness to drunkenness and gambling. All these concepts were then brought to a common denominator and termed Sarmatism, popularised in the play bearing the same title, created by Franciszek Zabłocki. Similarly 
to the Monitor, it presented a caricature of the Polish nobleman, a fallen and destructive individual, mainly consisting of a number of imperfections. Piotr Norblin took the same direction, when creating images of nobility from regional councils, embodied by drunks and troublemakers. This was also the case for Samuel B. Linde, the author of the famous and highly assessed Słownik jezzyka polskiego, issued at the beginning of the nineteenth century. In that work, the definition of Sarmatian was clearly negative. It said: "Pole; blunt, crude, old-fashioned swashbuckler", and Sarmatism was understood as "coarse manners, roughness" 3 . It is worth noting that Linde was a man of influence and opinion. He was prominent in educational authorities, the president of Towarzystwo do Ksiąg Elementarnych [Society for Elementary Books] at the University of Warsaw, as well as the rector of the Warsaw high school. Therefore, he had a huge influence on the creation of knowledge and awareness not only in his times, but also in future generations. The negative, insulting stereotype of the Sarmatian fixed by Linde's authority and identified with the Polish nobleman went into general circulation, and so far has remained alive, which is confirmed by contemporary arrangements ${ }^{4}$. This bogus stereotype seems to have ousted the good one. On this basis, any manifestation of the culture of gentry is subjected to the pejorative Sarmatism. It is possible to point out Sarmatian customs, costumes, portraits, memoirs, ways of fighting, mentality. This still negatively stigmatises not only the past of gentry, but also puts into question the national tradition. However, unrepresentative characteristics are representative, consciously faked defects, which, as noted by Stanisław Grzybowski, can be seen in the nobility of every country ${ }^{5}$.

Accordingly, the term "Sarmatism" should be considered biased, and thus scientifically ineligible, deprived of axiological and substantive distinctions. The etymology of the term stems from former Sarmatians. They were supposed to give rise to the native gentry and thus to justify its superiority against other classes. This theory was promoted by intellectuals like Jan Długosz, Maciej Miechowita, Marcin Bielski or Maciej Stryjkowski. Interestingly, this myth generally did not appeal to gentry members themselves. Obviously, they were aware of their genealogical heritage and valued their roots, but associated it mostly with their own coat of arms and lineage. I have analysed most of the memoirs from the $17^{\text {th }}$ and the $18^{\text {th }}$ century and have found no declarations on belonging to the Sarmatian descendants. Thus, it was not the gentry members who created and cultivated the Sarmatian myth; it was the scholars and writers who made it the subject of their works. Moreover, the myth came down only to one aspect of the gentry's culture, which was secondary to gentry members themselves. It is worth noting that the Sarmatian myth was born out of positive intentions on the part the authors, who probably tried to add to the splendour of Poland's policy-makers. However, due to persistent propaganda, this myth de facto became a stain which negatively determined the image of the whole class of gentry, its civilizational, cultural and legal contribution. Thus, to describe gentry, it is better to use the term of the culture of gentry referred to by e. g. Janusz Tazbir ${ }^{6}$, and not Sarmatism.

3 Linde B. Słownik języka polskiego. T. 5: R-T. Warszawa, 1995. S. 220-221.

4 Filip G., Patro-Kucab M. Obraz sarmatyzmu utrwalony w polskiej leksyce i przestrzeni społecznej wybrane zagadnienia i przykłady // Słowo. Studia Językoznawcze. 2013. Nr. 4. S. 53-71.

5 Grzybowski S. Sarmatyzm. Warszawa. 1996. S.7.

6 Tazbir J. Kultura szlachecka w Polsce. Rozkwit - upadek - relikty. Poznań, 1998. 
There is no doubt that the propaganda of the First Polish Republic significantly contributed to the creation of the negative stereotype of gentry. However, the peak of criticism, resulting in a permanently distorted image, came later. This would be the time of occupation, when gentry mostly acted against the foreign domination. It was that community, being the core of the state administration and army officers, and not the middle class and the peasants, who built the resistance, organised uprisings and fought battles. Thus, it constituted the only real opposition to the anti-Polish policy, and the only obstacle to a complete subordination of the nation. The price for the resistance was enormous: confiscation of property, imprisonment, exile, emigration or bloody provocations like the Galician slaughter. Physical extermination came along with economic extermination, implemented e. g. within the Colonisation Commission (Prussian occupation), and legal extermination divided into many stages, greatly contributed to the declassing or reduction in the number of gentry (Russian occupation). We should understand the enfranchisement reform in a similar way - although ultimately right, it was motivated by the best interests of the invaders. They became an effective tool for the implementation of anti-Polish policy. They directly translated into the intensified antagonism between gentry and peasants. In this context, the destruction of the authority of gentry may seem to have been an insignificant and irrational action, but in the long term, it led to the perpetuation of social divisions, unfavourable for not only of the reborn (after World War I) Second Republic, but for each state.

After a long smear campaign, the interwar period can be regarded as a positive interval marked with atrophy of collective and personal attacks directed against the authority of gentry. This does not mean, however, that this class was fully accepted and returned to the pre-occupation status quo. The political vision of the reborn Republic of Poland could not accommodate the former privileges or the oversized ownership of land. As a result, due to the enactment of the March Constitution, former titles and accompanying entitlements had lost all power, and due to the land reform the most valuable goods of gentry were partially divided up. Despite this, the state-building activity of noblemen, known from previous centuries, did not stop. They had a strong representation in the political, military and artistic world acquired thanks to the work, talents and skills, and not - as it was the case previously - deemed appropriate a priori under the applicable law ${ }^{7}$.

Gentry came away relatively unscathed from the interwar period, without a larger image loss. The situation changed drastically during the period of PRL. The architects of the post-war regime made noblemen the greatest class enemies. They undertook a number of actions in order to eliminate the class that could not fit the communist ideology. With all the ruthlessness and cruelty, the community decimated by war and occupation was deprived of property and was subjected to prison terror and judicial harassment. Those who managed to survive this were knocked on the margin of state life. Consequently, even after 1956, negative propaganda was present, increasing hostility based on past antagonisms and stereotypes strengthened by the myth of providing justice and social equality. The awareness, or "imaginarium" of the participants of the "overslept revolution", as Andrzej Leder ${ }^{8}$ describes the post-war processes, was injected with a negative image of the history of Poland, which suffered a defeat by the fault of the gentry, and, consequently,

7 Wiszowaty M. Dzieje szlachty polskiej w XX wieku i pierwszych latach XXI wieku // Pro Fide Rege et Lege. 2003. Nr. 1-2 (45). S. 22-27.

${ }^{8}$ Leder A. Prześniona rewolucja. Ćwiczenie z logiki historycznej. Warszawa, 2013. 
a negative image of that very gentry. To do this, they employed all the available means of impact - the contemporary media in the form of the press, radio, and, later, television. The film, theatre and literature served the same purpose. It seems, however, that the best effects were achieved in education. In all the history books, a gentry member was portrayed as a parasite living from exploitation and harm; as a notorious lump and rake; as a pest deliberately using abusive measures, such as liberum veto to implement private interest. The "truthfulness" of this version of the story was confirmed by the already mentioned iconography of Norblin. The iron canon of visual propaganda also includes the figure representing the pilloried peasant, present at each level of education. Eloquent images were accompanied by no less eloquent quotes, often taken out of context and distorted. This was the case with, among others, the famous definition of a horse (HORSE - everyone can see what it is), formulated by Benedykt Chemielowski in Nowe Ateny. Meanwhile, this sentence is only a part of a larger definition, as recently noted by Jacek Kowalski ${ }^{9}$, and only after reading the entire definition, can it be properly understood. We can find more of such communications repeated persistently. They can be a subject of a separate analysis, which out of scope of this paper. All of them were aimed at one goal - to raise negative emotions, to demote and to ridicule.

After 1989 and the return to democratic standards, there was a need to re-write history and to free it of communist ideology. Thus, the propaganda against gentry lost its justification. School book authors faced a serious challenge - they had to correctly understand the historical role of gentry in Poland. This resulted in a partial success. The state-making and culture-making contribution of gentry was recognised. However, it was not possible to avoid the old critical manners, making the odium imposed on gentry for centuries still alive. This is confirmed by the repeatedly reproduced images of the said pilloried peasant, accompanied by anti-gentry accusations of megalomania, xenophobia, intolerance, conservatism, roughness and narrow-mindedness. Such accusations are found not only in the curriculum, but also on popular educational portals like Profesor.pl, Ściaga. pl, Szkolnictwo.pl or Bryk.pl. Most opinions formulated in there are not only unfounded, just like drawing conclusions about the majority of people on the basis of criminal records, but also inconsistent, as e.g. the accusation of xenophobia contradicts the accusation of succumbing to Oriental or Western fashion.

The analysis of textbooks combined with the observation of the online content leads to the conclusion that the evaluation of gentry is too often accompanied by previously developed notions, which repeat the negative stereotype. In order to assess its importance and influence on consciousness, I decided to carry out surveys on a selected group of students of high schools in Zielona Góra, and students of history and doctoral candidates of the University of Zielona Góra. The sample is not random. I assumed that this group, historically aware, is the most representative media not only for the current state of knowledge, but also for stereotypes developed through the ages. The research tool was the survey, divided into two parts. In the first part, the respondents (a total of 173 people, including 92 high school students, 48 university students, 33 doctoral candidates) wrote down the advantages and disadvantages of the Polish knightry, and the advantages and disadvantages relating to gentry. The results obtained are shown in the following table.

${ }^{9}$ Kowalski J. Sarmacja. Obalanie mitów. Podręcznik bojowy. Warszawa. 2016. S. 203-211. 
The advantages and disadvantages of the Polish knightry / member of gentry

\begin{tabular}{|l|c|c|c|c|c|c|c|c|}
\hline \multirow{2}{*}{ Rating } & High school students & University students & Doctoral candidates & \multicolumn{2}{|c|}{ Total } \\
\cline { 2 - 9 } & Number & $\begin{array}{c}\text { Propor- } \\
\text { tion, \% }\end{array}$ & Number & $\begin{array}{c}\text { Propor- } \\
\text { tion, \% }\end{array}$ & Number & $\begin{array}{c}\text { Propor- } \\
\text { tion, \% }\end{array}$ & Number & $\begin{array}{c}\text { Propor- } \\
\text { tion, \% }\end{array}$ \\
\hline Positive & $88 / 6$ & $95,7 / 6,5$ & $40 / 8$ & $83 / 17$ & $30 / 6$ & $91 / 18$ & $158 / 20$ & $91 / 12$ \\
\hline Negative & $0 / 76$ & $0 / 82,6$ & $0 / 24$ & $0 / 50$ & $0 / 18$ & $0 / 55$ & $0 / 118$ & $0 / 68$ \\
\hline No opinion & $4 / 10$ & $4,3 / 10,9$ & $8 / 16$ & $17 / 33$ & $3 / 9$ & $9 / 27$ & $15 / 35$ & $9 / 20$ \\
\hline
\end{tabular}

The first table includes a split into levels of education. It shows that, in general, all the respondents, not counting the fractional deviation, positively assessed medieval knightry. In their opinion, this group was largely characterised by advantages, such as courage, loyalty, generosity, honour, idealism, the ability to make sacrifices, etc. A few mentioned the disadvantages associated with a propensity to violence, rape and aggression, but the latter did not really impact the unequivocally positive image of knights. The situation is opposite for gentry. According to the respondents, gentry was primarily characterised by flaws in the form of conservatism, private interests, arrogance, greed, selfishness, ignorance, laziness, arbitrariness, iniquity, cowardice, lack of moderation in consumption, possession and pursuit of power, and parasitic life at the expense of the lower classes. These are just some, most often repeated accusations from the repertoire of anti-gentry criticism. Nevertheless, there is a tendency: the higher the education level, the less criticism. University students and doctoral candidates are less categorical in the formulation of charges and are able to see the positive side of gentry more often than high school students. This does not change the fact that in the final analysis, the axiological superiority of knightry over gentry cannot raise any doubts. It is visible on charts constructed based on the results (Figs 1,2).

They allow me to make a conclusion on the permanent presence of two opposing stereotypes: the good knight and the evil nobleman. This conclusion mainly concerns the historical consciousness of the examined group of students and doctoral students. However, it's possible to hypothesize that this kind of perception of the history of Poland is a phenomenon embedded in the common consciousness. This is evidenced by slogan, nowadays very popular on social media: "Gentry does not work". Recently, this type of message appeared on a poster of one of the political groups. Perhaps we should read it through the prism of stereotypical knowledge of the authors themselves, which of course does say a lot about them, and perhaps it has been used deliberately in order to trigger negative associations which actually deserves a reprimand. The slogan enjoys great popularity on social networks. Its users, usually young people, consequently type it in the employment box on their profiles. It is a stereotype in pure form, free of current propaganda purposes. On the one hand, it shows a conviction that gentry is a lazy class because they do not work, at least in the physical sense, in which one can easily see axiology from PRL. On the other hand, it is hard not to notice that clear fashion for such a declaration is a manifestation of a kind of admiration for gentry - and more specifically — for its alleged cleverness that allows for an effortless, rich and lavish life. 


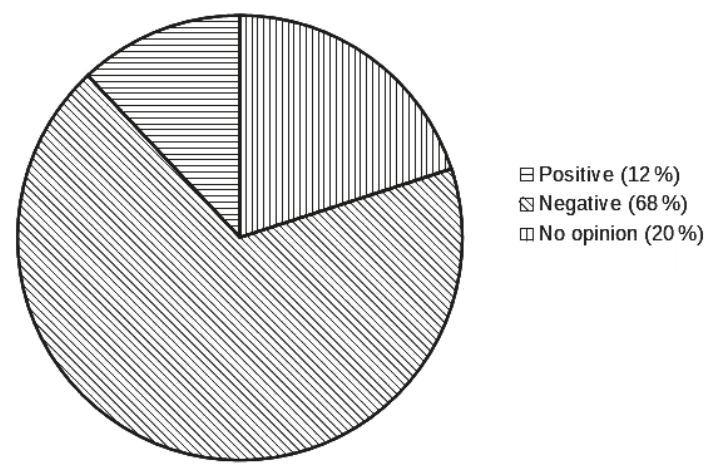

Fig. 1. Opinion on gentry

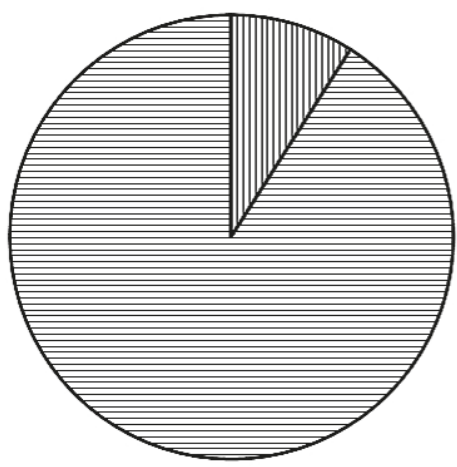

日Positive (91\%) $\triangle$ Negative $(0 \%)$ m No opinion ( $9 \%$ )

Fig. 2. Opinion on knightry

Thinking based on false premises and resulting in a black-and-white understanding of the historical process is far from the actual dimension. It is not possible for medieval knights to have only positive characteristics, and for their continuers - gentry - to be a personification of flaws and to be prone to destruction. Moreover, in the state axiological system, which is convincingly argued by the moralistic literature of the era, there is no consent for the primacy of personal matters over the public ones, and also for laziness, for the lack of moderation, oversized consumption or entertainment. Moral standards written by gentry and for gentry focused on the requirements of genealogical, personal, professional and social excellence. In order to aspire to the title of a role-model, one had to be noble-born and noble-hearted. His coat of arms had to be accompanied with an inner integrity, a virtue, and he had to be able to meet the assigned duties. The latter were related to effective management, a competent clerical and diplomatic service, engagement in the parliamentary and political affairs, with readiness to fight as a soldier, and with a courtly culture. Micro- and macro-liabilities were no less important. The first ones included being a good son, husband and father; a good master for the subjects, and a benevolent neighbour. The second concerned the implementation of the requirements posed against exemplary citizens, obliged to an ongoing concern about the fate of Poland, to the activity for the sake of its good and positive emotions, or patriotism of the highest order. Belonging to a religious community was equally important, which in the case of old Polish gentry was 
reflected in the image of the perfect Christian, usually an ardent Catholic, emphasising the collective and personal relationship with $\mathrm{God}^{10}$.

Thus, the gentry's system of values, due to the multiplicity and quality of expectations, was difficult to adhere to, yet most noble diarists aspired to do so. We also know that there were some exceptions in this respect, which is confirmed in criminal records. Still, we cannot judge the whole community in the context of its margins as such an evaluation would always be illegitimate and unfair. Therefore, proper verification criterion for gentry is the quality of the promoted standards in the personal and social field, as well as a reliable and objective assessment of the contribution to the political, economic, parliamentary and cultural shape of Poland. This contribution was indeed appreciated by many historians, which probably paved the way for the currently ongoing discussion about the Sarmatism ${ }^{11}$. There is no doubt, however, that the stereotype is generally holding up well. It is obviously harmful to our identity and consciousness. Through the distortion of history and negation of the historical role of gentry, the sense of national community is abused; the long-term cultural heritage is rejected. One visible result of this process is the emergence of the postmodern role-models (tourist, vagrant, stroller, player) classified by Zygmunt Bauman ${ }^{12}$.

The practice of denial and displacement of gentry's tradition is not, in any case, identical to its complete disappearance. It still functions in the universal consciousness as a native value, appreciated but not named. In this sense, we are all its heirs. Despite the efforts of communist authorities, we do not turn to each other per citizen or comrade, nor in a plebeian manner, evident in phrases such as "wy" [plural form of "you" in Polish, typical addressing to a single person by communists]. Unlike most nations, we use "Sir" or "Mad$a m$ " in addressing each other. We gain from gentry's traditions on occasions like a name day, we enjoy the fashion to search for our noble ancestors, we like to be surrounded with old objects and relics. We also want to settle away from the urban hustle and bustle, often in houses that architectonically reflect the mansions of gentry, with a characteristic façade, porch and columns. Just as those nobles, we value our identity, individuality and privacy. We protect our honour and civil liberties. We use the old, though not clearly understandable cultural code, yet we fail to see the axiological patina and meaning to our identity.

\section{References}

Bauman Z. Dwa szkice o moralności ponowoczesnej. Warszawa, Instytut Kultury, 1994, 88 s.

Filip G., Patro-Kucab M. Obraz sarmatyzmu utrwalony w polskiej leksyce i przestrzeni społecznej — wybrane zagadnienia i przykłady. Słowo. Studia Językoznawcze, 2013, nr. 4, ss. 53-71.

Grzybowski S. Sarmatyzm. Dzieje narodu i państwa polskiego. Kraków, Krajowa Agencja Wydawnicza, 1996, $75 \mathrm{~s}$.

Klik M. Teorie mitu. Współczesne literaturoznawstwo francuskie (1969-2010). Warszawa, Uniwersytet Warszawski, 2016, 419 s.

Kowalski J. Sarmacja. Obalanie mitów. Podręcznik bojowy. Warszawa, Zona Zero, 2016, $400 \mathrm{s.}$

10 Świderska-Włodarczyk U. Homo nobilis. Wzorzec szlachcica w Rzeczypospolitej XVI i XVII wieku. Warszawa, 2017.

11 The participants of the discussion and the polarisation of positions are described in the following article: Zielińska K. Pustka zwana narodem czy mit wiecznie żywy? O różnych obliczach sarmatyzmu dawnego i współczesnego // Szkice Humanistyczne”. T. XVI, nr. 3 (40). 2016. S. 37-46.

12 Bauman Z. Dwa szkice o moralności ponowoczesnej. Warszawa, 1994. 
Leder A. Prześniona rewolucja. Ćwiczenie z logiki historycznej. Warszawa, Wydawnictwo Krytyki Politycznej, 2013, 208 s.

Linde S. B. Słownik języka polskiego. T. 5: R-T. Lwów. 1859. Warszawa, Wydawnictwo Gutenberg-Print, 1995, $372 \mathrm{~s}$.

Samsonowicz H. O "historii prawdziwej". Mity, legendy i podania jako źródło historyczne. Gdańsk, Wydawnictwo Novus Orbis, 1997, $206 \mathrm{~s}$.

Świderska-Włodarczyk U. Homo nobilis. Wzorzec szlachcica w Rzeczypospolitej XVI i XVII wieku. Warszawa, Wydawnictwo Naukowe PWN, 2017, 240 s.

Tazbir J. Kultura szlachecka w Polsce. Rozkwit - upadek - relikty. Poznań, Wydawnictwo Poznańskie, 1998, $244 \mathrm{~s}$.

Wiszowaty M. Dzieje szlachty polskiej w XX wieku i pierwszych latach XXI wieku. Pro Fide Rege et Lege, 2003, nr. 1-2 (45), ss. 22-27.

Zielińska K. Pustka zwana narodem czy mit wiecznie żywy? O różnych obliczach sarmatyzmu dawnego i współczesnego. Szkice Humanistyczne, 2016, t. XVI, nr. 3 (40), ss. 37-46.

Статья поступила в редакцию 2 февраля 2020 г.

Рекомендована в печать 12 марта 2020 г.

Received: February 2, 2020

Accepted: March 12, 2020 